Historic, Archive Document

Do not assume content reflects current scientific knowledge, policies, or practices. 



\section{Another \\ Scale Insect on Beech}

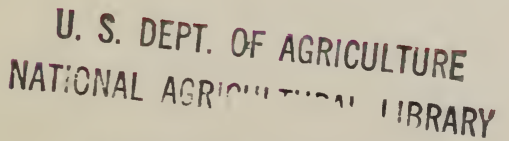
NOV 281962 by Alex L. Shigo

STATION PAPER, NO. 168 - NORTHEASTERN FOREST EXPERIMENT STATION • 1962 FOREST SERVICE, - U.S. DEPARTMENT OF AGRICULTURE - UPPER DARBY, PA. RALPH W. MARQUIS, DIRECTOR 


\section{The Author--}

ALEX L. SHIGO received bis B.S. degree in biology at Waynesburg College, Waynesburg, Pennsylvania, in 1956. He received bis M.S. degree in 1958 and bis Ph.D. in plant patbology in 1959, at West Virginia University. He joined the U.S. Forest Service in September I9s9 and is serving as forest patbologist at the Northeastern Forest Experiment Station's research center at Laconia, New Hampshire. 


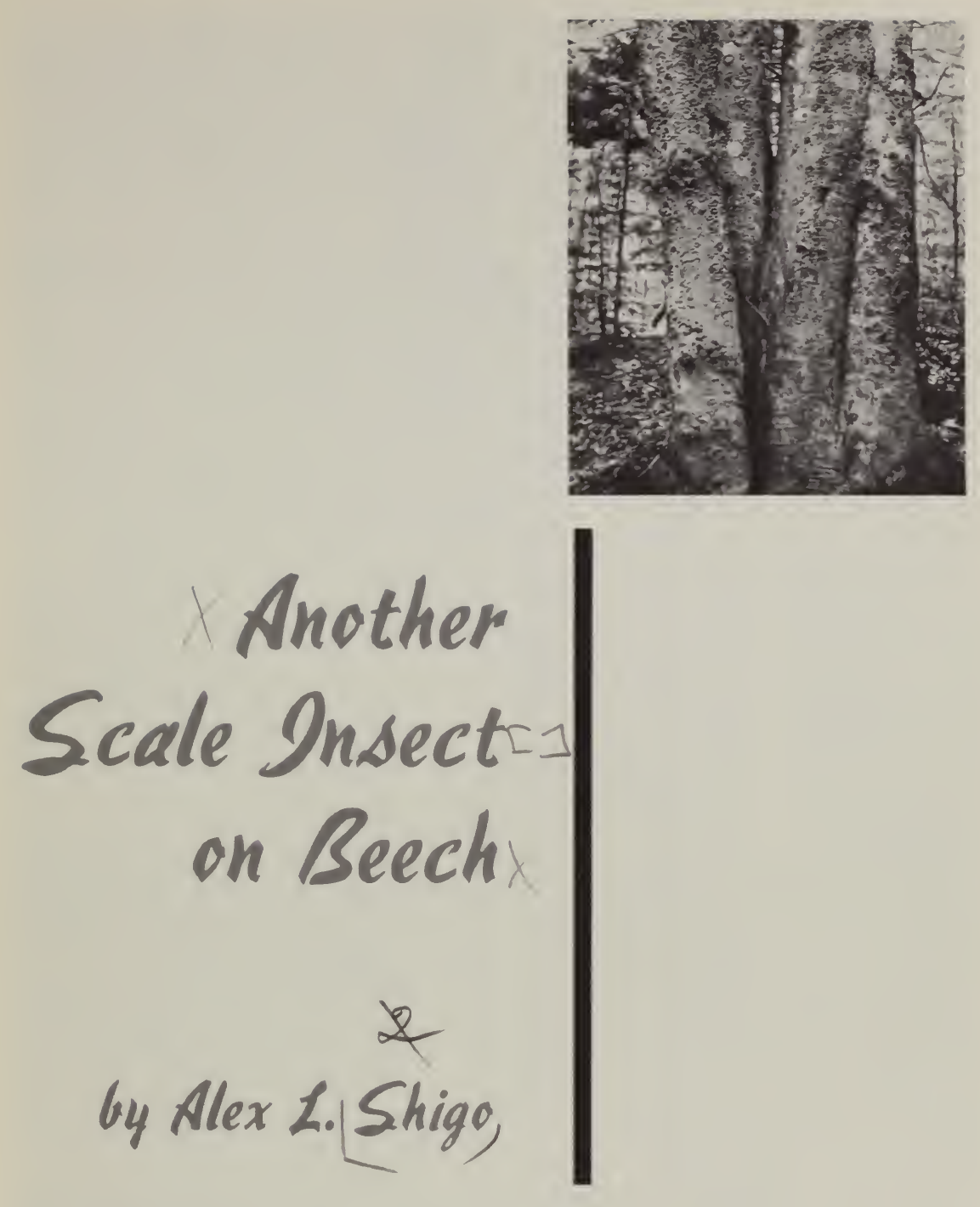

A SCALE INSECT, tentatively identified as Xylococculus betulae (Perg.) Morrison, is responsible for one type of bark roughening that is commonly seen on American beech (Fagus grandifolia Ehrh.) trees in certain areas of New England. The insect has also been found on paper birch (Betula papyrifera Marsh.) and yellow birch (B. allegheniensis Britton).

The roughening caused on beech bark by $X$. betulae is often mistaken for some types of bark injury that result from the 
beech bark disease, which is caused by a bark-killing fungus (Nectria coccinea var. faginata Lohman, A. J. Wats., and Ayres) that apparently infects the tree through minute wounds and cracks resulting from the feeding of an insect, the beech scale (Cryptococcus fagi Baer.) (Ehrlich, 1934).

The beech bark disease has been killing beech in the forests of the Northeast at an alarming rate since 1920. A high percentage of the trees have been infected, and most of the different types of bark roughening seen on beech trees have been attributed to this disease. Very little research has been done on this disease since 1934. This may be one reason why $X$. betulae has not received more attention.

The purpose of this paper is to point out the differences between the bark injuries caused by $X$. betulae and those caused by the beech bark disease. Some observations on $X$. betulae are also offered.

\section{Bark Injuries}

The roughening of beech bark caused by $X$. betulae appears as swollen spots $1 / 2$ to 2 inches in diameter, usually with longitudinal slits through the middle (fig. 1 and fig. 2). As these spots become older and drier, additional cracks form around them. Callus tissue forming around these dead spots accentuates the already roughened bark. These erumpent spots are begun by the feeding activities of $X$. betulae.

The bark injuries caused by the beech bark disease are somewhat different. They may take three different forms:

1. The bark remains fairly smooth on trees that have had their entire bole girdled by one large Nectria lesion. Eventually the bark splits on these trees and falls off in plates (fig. 3).

Figure 1.-The bark of this beech tree was roughened by the scale insect $X y l o c o c c u l u s$ betulae. The areas around branch stubs were attacked by the coccid, and later became infected by a fungus of the Nectria genus. On some trees the attacked areas became depressed. 


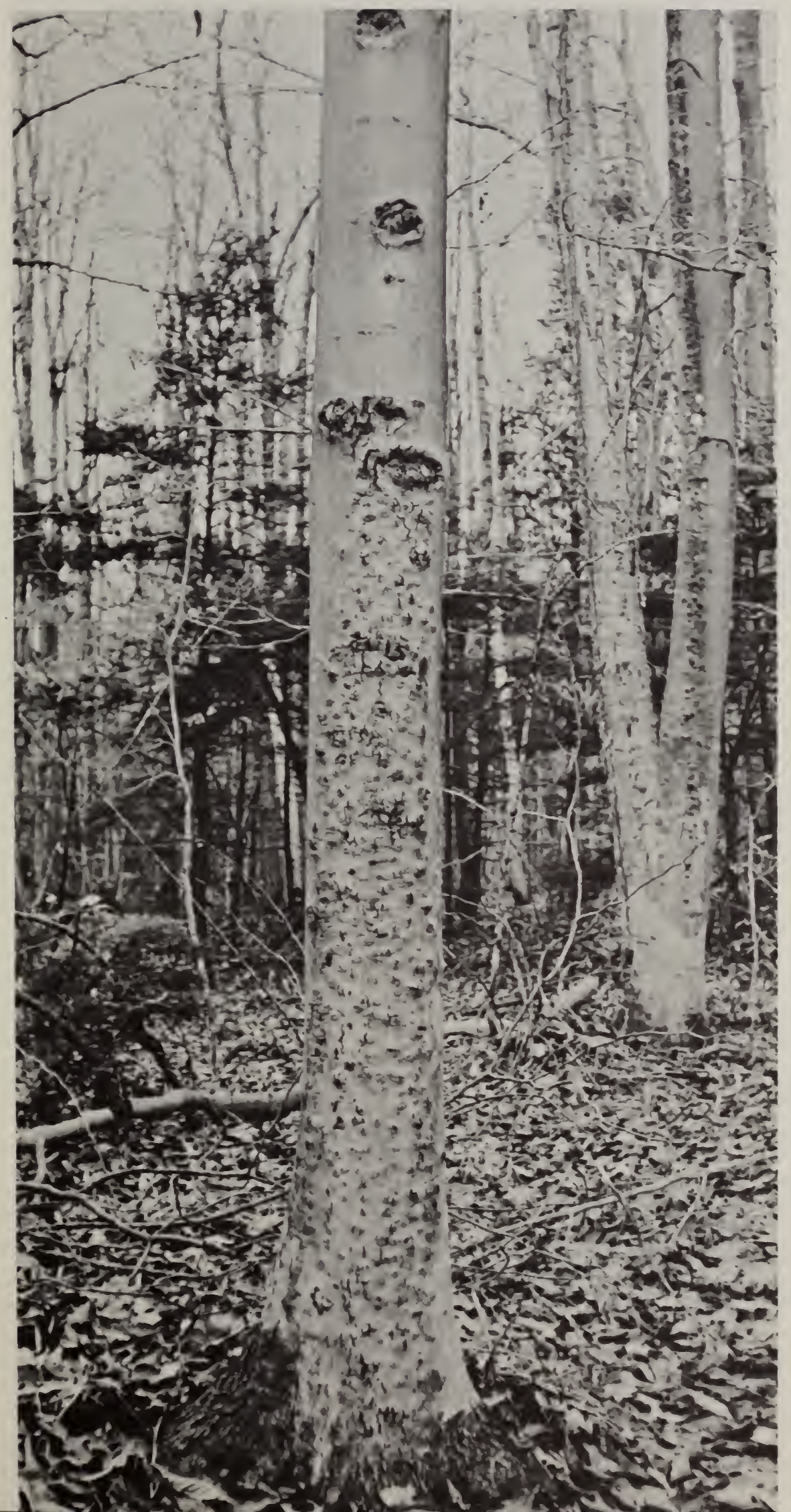


Figure 2.-Close-up view of erumpent spots on a beech tree, caused by feeding wounds by $X$. betulae. The wounds were later infested by the beech scale, Cryptococcus fagi.

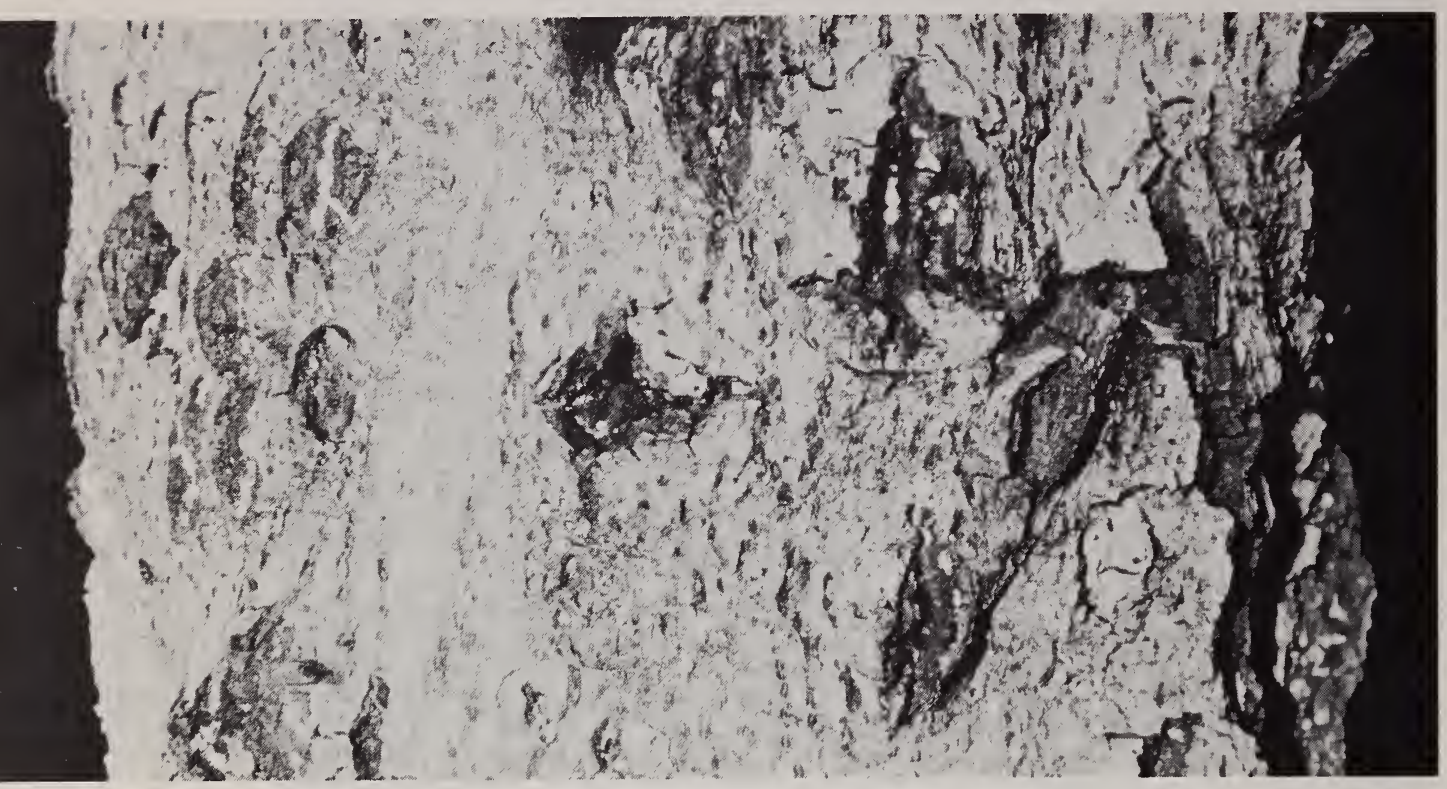

2. Callus formation is stimulated between large nongirdling Nectria cankers, and the bark becomes very roughened with long longitudinal cracks. Secondary fungi quickly invade these areas (fig. 4).

3. Isolated small Nectria cankers are occasionally walled off from the sapwood by callus tissue. The edge of each small raised canker is smooth, and trees with many of these cankers have a knobby appearance (fig. 5).

The second and third types of bark roughening are sometimes found on the same tree.

\section{The Insect}

Xylococculus betulae is an orange-red, soft-bodied scale insect, approximately $4 \mathrm{~mm}$. long at maturity. The female has five stages and the male six. The adult male has wings. The insect's body is covered with glands that secrete a white wax. 


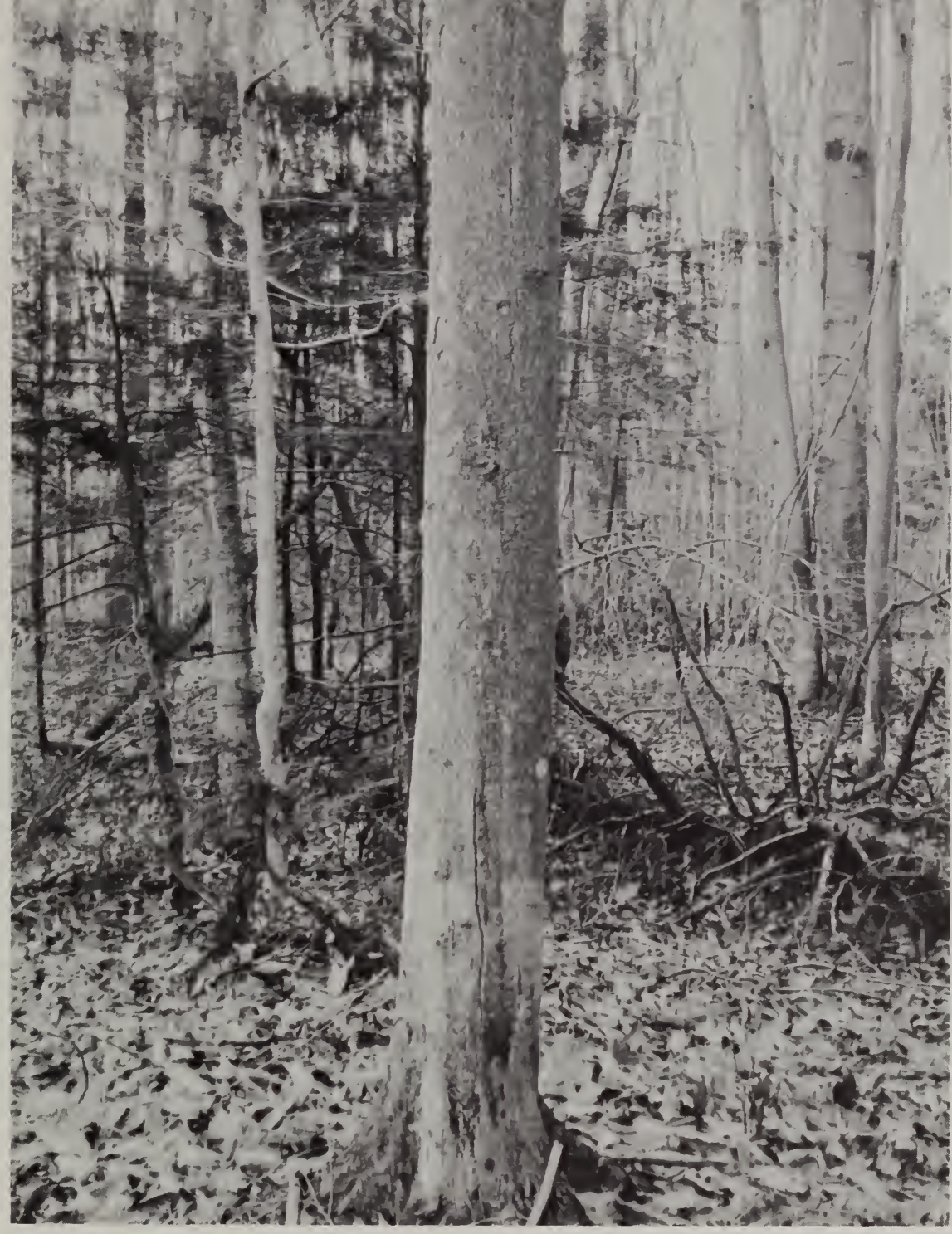

Figure 3.-An American beech tree killed by the beech bark disease. Here the bark on the entire bole was killed by the fungus. The bark remains fairly smooth on such trees until it falls off in plates.

The female insect is a memberless sac during its growth in the bark. However, the adult female is capable of enough locomotion so that she can move out of her cell in the bark to the edge of the small crevice during fertilization. The eggs are deposited in the cell.

The emerging larvae have legs, and they quickly crawl into lenticels and roughened spots on the bark. The insect begins to 
Figure 4.-The fungus fruiting bodies (Hypoxylon sp. and Fomes igniarius) on this beech tree indicate secondary infections on the smooth lesion caused by an attack by the Nectria. The longitudinal cracks in the bark resulted from callus formation around the lesion.

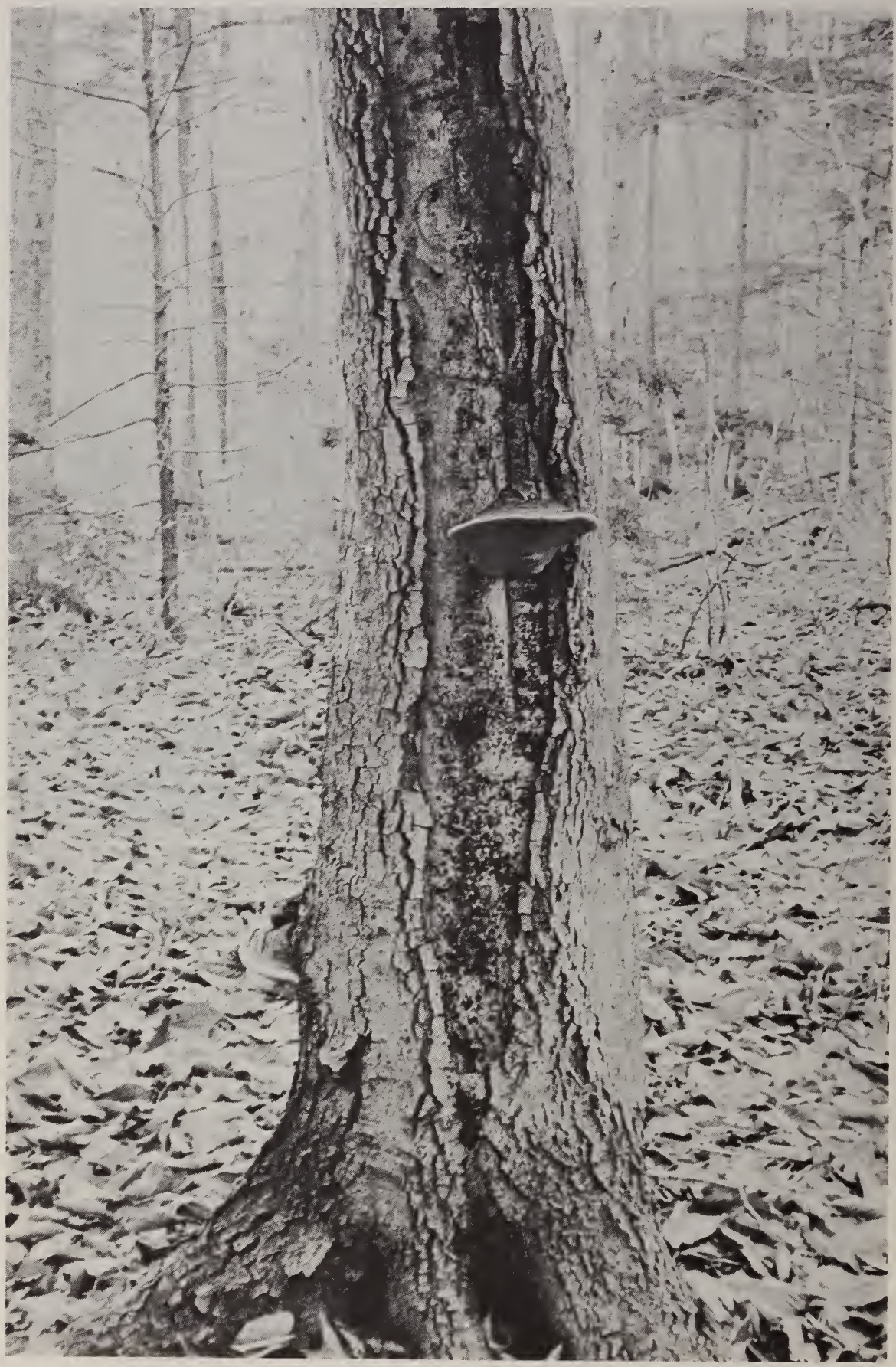




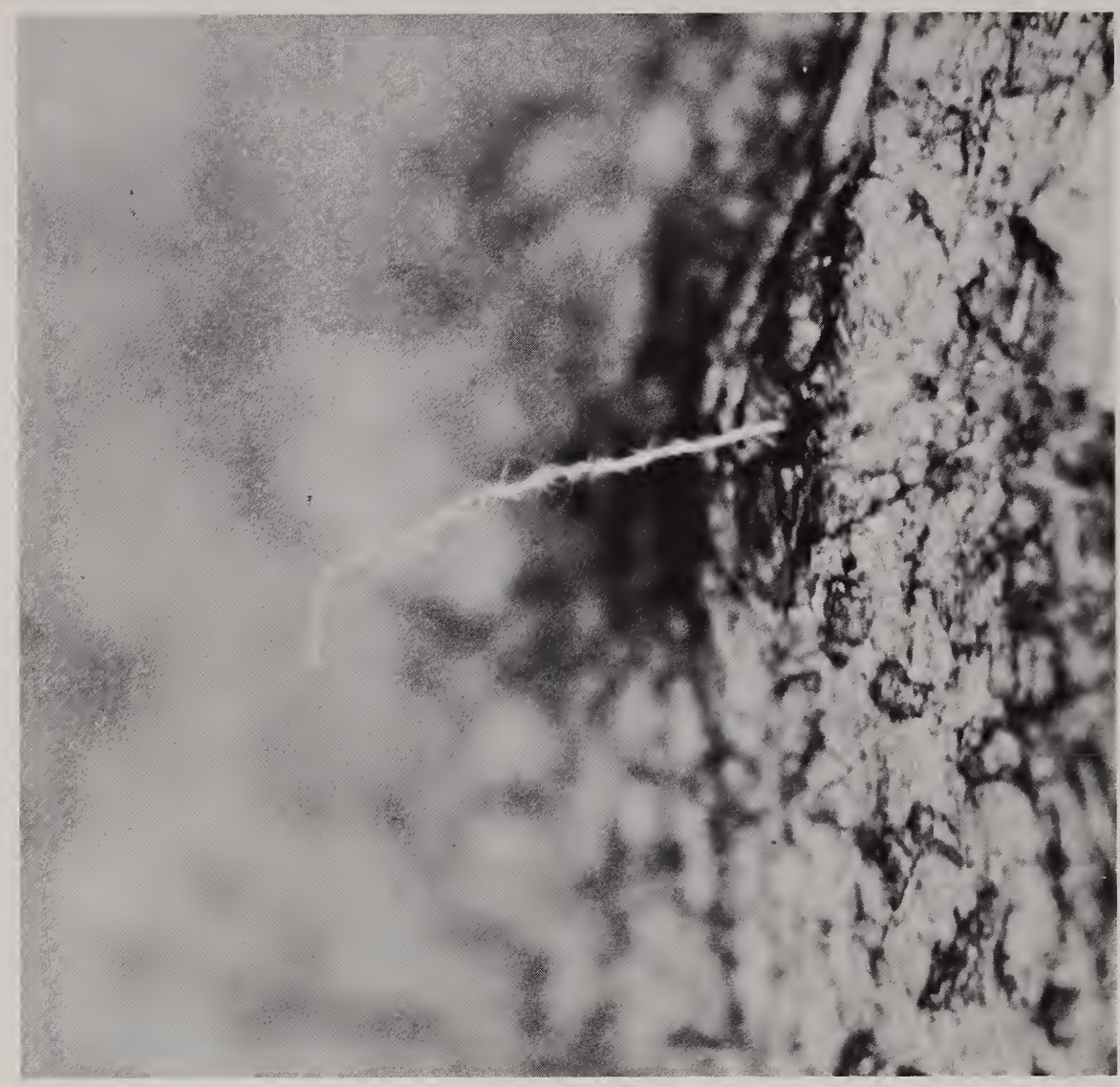

Figure 6.-This white and waxy excretory tube protruding $1 / 2$ inch out of the small hole in the bark indicates the presence of the scale insect $X$. betulae.

feed by forcing a long stylet into the bark. Shortly after this it loses its legs and secretes a mass of wax around itself, forming a pearl-like cell.

The honeydew or saccharine excrement of the insect is passed out of a hairlike wax tube ranging from $1 / 2$ to 2 inches long, which is formed from wax rods protruding from the anus (fig. 6). Small glistening droplets form on the tip of the tube when the insect is feeding. These white hairlike tubes can be seen in great abundance on many trees in the summer. The crevices in the bark continue to enlarge as other coccids of this species force their way deeper into the bark (Hubbard and Pergande, 1898). 


\section{History and Distribution}

Hubbard and Pergande first reported Xylococcus betulae Perg. in 1898 as a new coccid that causes injury to birch, and gave a detailed account of its life history. In 1928 Morrison assigned this American species to a new genus, Xylococculus, but did not change the specific name. No mention was made of this insect attacking beech.

In 1931 the beech scale was found in Maine in Waldo, Charlotte, and Washington Counties. In 1933 Dr. A. E. Brower, entomologist of the Maine Forest Service, recognized a second scale on beech on Mt. Desert Island (Maine Forest Service, 1934). This coccid was later considered by him as a serious pest on paper birch near Bar Harbor (Maine Forest Service, 1942).

In 1959 X. betulae was first reported on beech and yellow birch in the Maritime Provinces of Canada, and in scattered locations in northern and central New Brunswick. Only small numbers were found (Forbes et al. 1959). In the same year, the insect was observed by the author on many beech, paper birch, and yellow birch trees around Bartlett, New Hampshire. The scale has also been observed on beech in Vermont and New York. ${ }^{1}$ In 1960, it was reported for the first time in Nova Scotia in Colchester, Pictou, and Queen's Counties (Forbes et al. 1960).

\section{Damage}

The large, orange-red coccids that the author observed on beech, yellow birch, and paper birch around Bartlett, New Hampshire, all appeared to be of the same species. Necrotic areas several inches in diameter were noted on some yellow and paper birch trees attacked by the coccids. The crowns of beech trees cut for other reasons were examined; it was found that the upper branches were frequently attacked, whereas the main stems

\footnotetext{
${ }^{1}$ Paul V. Mook, forest pathologist, Forest Disease Laboratory, Northeastern Forest Experiment Station, U. S. Forest Service, New Haven, Conn. Personal communication, I962.
} 
were clear. The coccids seemed to attack the under side of branches first.

As the insects multiply, the crevices in the bark continue to deepen. These well-protected crevices are often infested by the beech scale (fig. 2). Perithecia of Nectria spp. are commonly seen around the wounds, indicating local infections. A species of Nectria other than the one commonly associated with the beech scale was isolated from some of the wounds. Other investigators have isolated a Nectria other than $N$. coccinea var. faginata from beech-scale-infested trees (Spaulding et al. 1936). It is possible that the isolations were made from areas near wounds made by $X$. betulae.

On some trees, the erumpent spots are found over the entire bole; but usually they are in narrow longitudinal strips that start at old branch stubs. The insects may be carried down the tree stem by water to new locations below the branch stubs, or they may have a definite preference for these areas that are usually more moist. This is just another example of the hazard presented by retention of old branches and stubs on a tree. The living tissues around infested stubs are killed, and in extreme cases the area around the stub is depressed instead of healed over (fig. 1). Nectria species also have been isolated from these necrotic spots. Even on trees free of $X$. betulae, branch stubs are the most important infection courts for canker-forming Nectrias (Grant et al., 1938).

The possibility exists that the winged males of $X$. betulae could carry Nectria spores from one tree to another during mating flights. More research is needed before this can be proved.

The extreme bark roughening caused by $X$. betulae does not result in as much damage to the tree as the large, smooth, girdling lesions resulting from infections of $N$. coccinea var. faginata following the attack of $C$. fagi. However, the dead areas and bark inclusions caused by $X$. betulae do substantially degrade the tree for the production of quality lumber products. Secondary fungi, especially species of Hypoxylon, quickly invade the sapwood beneath the large, smooth Nectria lesions caused by the beech bark disease (fig. 4); whereas the injuries caused by $X$. 


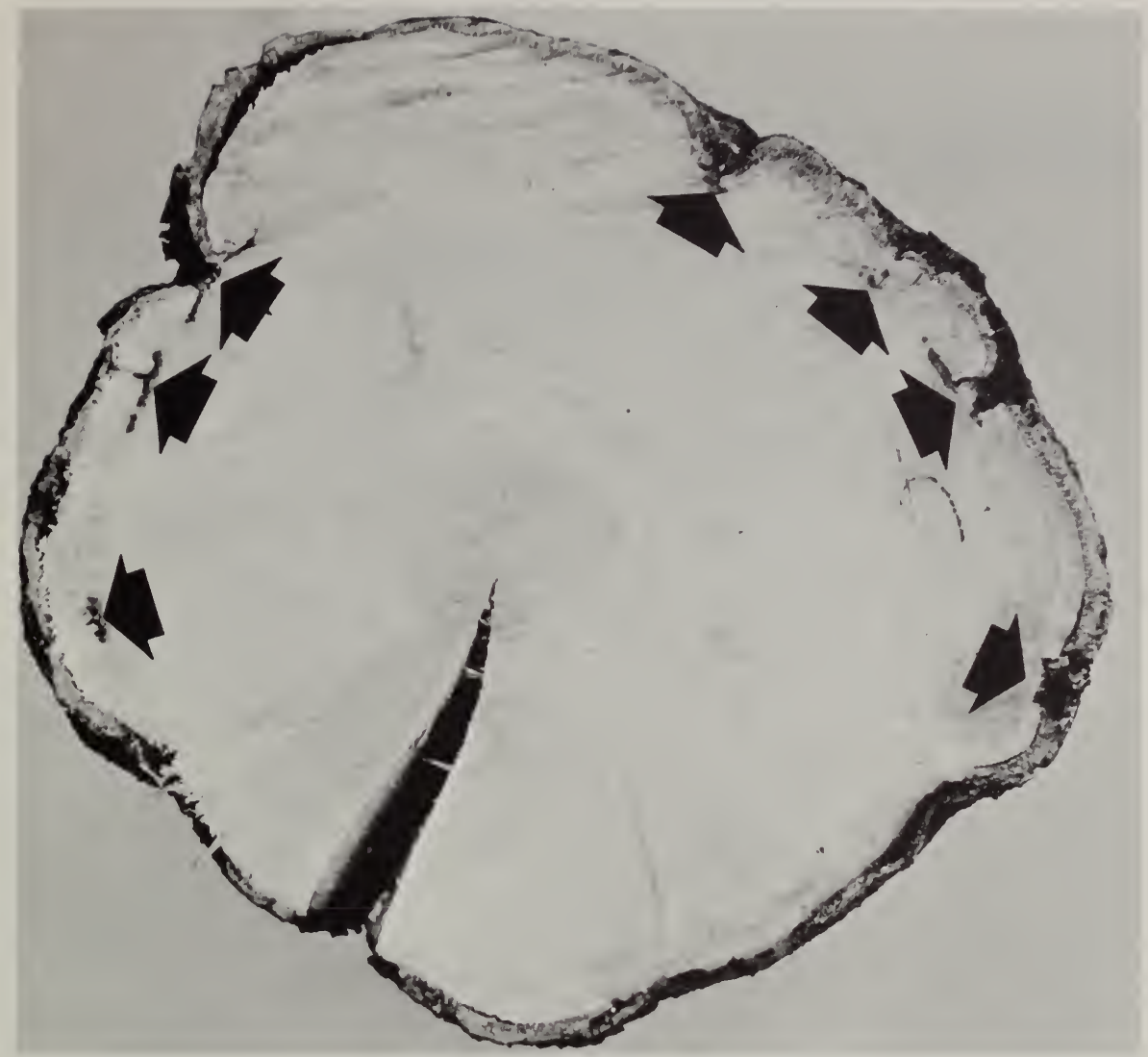

Figure 7.-The arrows on this cross-section of a beech stem indicate areas attacked by $X$. betulae. The necrotic smooth side of the stem opposite the arrows was killed by $N$. coccinea var. faginata after an infestation by $C$. fagi.

betulae are usually walled off by callus tissue (fig. 7). Even if the wounds caused by $X$. betulae are infected by Nectria species, these slow-growing fungi seldom grow outside the callus tissue. But perithecia on these erumpent areas do provide an abundance of inoculum to infect wounds made by the feeding of $C$. fagi .

Often both scale insects and species of Nectria are found on the same tree. Trees on which Nectria cankers are delimited by callus tissue usually are not killed, but live for many years in a very weakened condition, and are of no value for lumber.

Vigorous beech trees, free of both scale insects and Nectria, are often found growing next to trees attacked by one or all of 
Figure 8.-The vigorous, clean-stemmed beech on the left is free of both scale insects and Nectria even though it is growing next to a tree attacked by $X$. betulae and near one (background) that was girdled after a severe infection by beech bark disease.

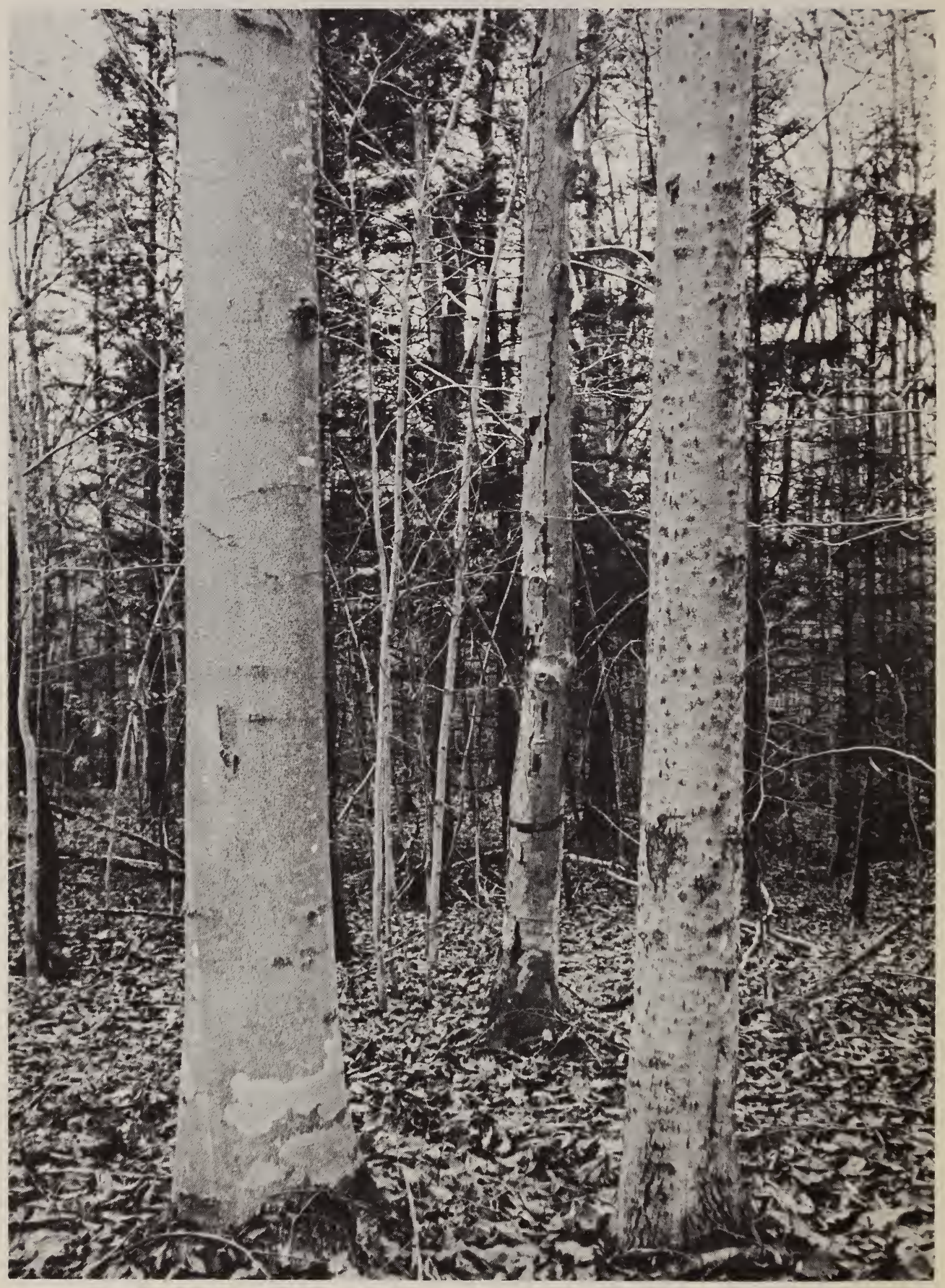


these destructive organisms (fig. 8). The possibility that some trees might have genetic resistance to attack by the beech scale has been proposed (Thomsen et al. 1949). More light on this would be of great value to those concerned with growing quality beech. Why certain trees are not attacked by $X$. betulae also remains an unanswered question. Nothing on this subject has been found in the literature. Trees attacked by $X$. betulae alone can be of value if they are cut during the early stages of injury.

The spread of this coccid in the beech forests and its close association with species of Nectria and C. fagi make the beech scale-Nectria complex even more complex.

\section{Literature Cited}

Ehrlich, J.

1934. The beech bark disease, a Nectria DISEASE OF FAGUS, FOLlowing Cryptococcus fagi (Baer). Canada Jour. Res. 10:593-692.

Forbes, R. S., Underwood, G. R., Cuming, F. G., and Eidt, D. C.

i959. Maritime Provinces, Forest Insect Survey. In Annual Report of Forest Insect and Disease Survey. Canada Dept. Agr. I2I pp.

ig6o. Maritime Provinces, Forest Insect Survey. In Annual Report of Forest Insects and Disease Survey. Canada Dept. Agr. I2I pp.

Grant, T. J., and Spaulding, P.

1938. AVENUES OF ENTRANCE FOR CANKERforming Nectrias of New ENGLAND Hardwoods. Phytopathology 29: $35 \mathrm{I}-358$.

Hubbard, H. G., and Pergande, T.

I898. A NEW COCCID ON BIRCH. U.S. Dept.
Agr. Div. Entomology Bull. I8 (n.s.): I3-26.

Maine Forest Service.

I934. TWentieth bienNial Report of the Forest Commissioner, I933-34. Augusta. $70 \mathrm{pp}$.

I942. TWENTY-FOURTH BIENNIAL REPORT OP the Forest Commissioner, I94I-42. Augusta. $37 \mathrm{pp}$.

Morrison, $\mathrm{H}$.

I929. A CLASSification OF THE HigheR GROUPS AND GENERA OF THE COCCID family Margarodidae. U. S. Dept. Agr. Tech. Bull. 52. 240 pp.

Spaulding, P., Grant, T. J., and Ayers, T. T. I936. Investigations of Nectria diseases in HaRdwoods OF New ENGLaNd. Jour. Forestry 34: 169-179.

Thomsen, M., Buchwald, N. F., and Hauberg, Paul.

1949. Angreb of Cryptococcus fagi, Nectria galligena OG ANDRE PARASITER PAA B $\phi \mathrm{G}$ I Danmark I939-43. Forstl. Forsg $\phi$ sv. i Danmark. I8: Beret. I57. (English summary.) $230 \mathrm{pp}$. 


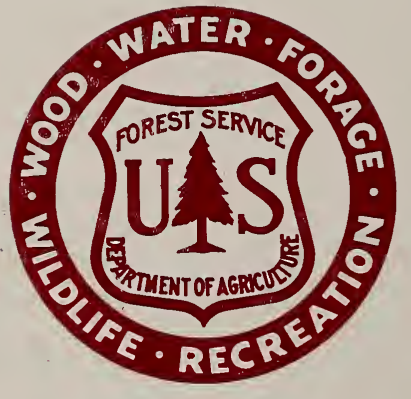

